\title{
A NOTE ON THE MATING BEHAVIOUR OF EWES WITH VARIOUS SENSES IMPAIRED
}

\author{
P. D. MORGAN, ${ }^{*}$ G. W. ARNOLD $\ddagger$ \\ AND D. R. LINDSAY* \\ * Institute of Agriculture, University of Western Australia, \\ Nedlands, Western Australia 6009, and \\ $\uparrow$ CSIRO, Division of Plant Industry, Private Bag, \\ P.O. Wembley, Western Australia 6014
}

(Received 7th December 1971, accepted 8th February 1972)

\begin{abstract}
Summary. Observations were made of mating and pregnancy in intact Border Leicester $\times$ Merino ewes and in ewes with the senses of hearing, touch around the mouth and/or smell impaired. During November and December, almost all ewes with the sense of smell mated and became pregnant; less than half the ewes with smell impaired mated and became pregnant. It is suggested that rams stimulate oestrous activity in non-cycling ewes through olfactory receptors in the ewe.
\end{abstract}

The importance of the senses of sight, smell and hearing in ram-seeking behaviour in oestrous ewes has been demonstrated by Fletcher \& Lindsay (1968). However, the rôle of the senses in other aspects of reproductive behaviour such as the onset of oestrous activity following anoestrus is unknown, but has been shown (especially the sense of smell) to be vital in other species (Parkes \& Bruce, 1961; Signoret \& Mauléon, 1962). The presence of rams is known to have a stimulating effect on oestrous activity at the onset of the breeding season (Underwood, Shier \& Davenport, 1944; Thompson \& Schinckel, 1952; Schinckel, 1954). Watson \& Radford (1960) showed that the effect was not dependent on visual and tactile cues.

The following observations were made on sixty-seven Border Leicester $\times$ Merino ewes with various senses impaired, which were being used for studies on the relationship between the senses and maternal behaviour (to be reported later). Senses of smell and touch were impaired according to the techniques described by Chapman (1965) and hearing according to a modification of the technique described by Grono (1962). In the absence of electrophysiological equipment, it was not possible to determine the degree of impairment. However, when these ewes were tested for maternal behaviour, ewes with sense of smell and/or hearing impaired behaved quite differently from intact ewes, indicating that techniques used for the impairment of the senses had been effective. Ewes were kept with rams ('joined') for 8 weeks during November and December 1968. Mating activity was identified by the use of sire-sine

† Present address: Department of Agriculture, Derby, Western Australia 6728. 
harnesses and crayons. All ewes were subjected to laparotomy for pregnancy diagnosis in January and February 1969.

Six of the fifteen ewes with sense of smell impaired (five pregnant), all sixteen with senses of touch and/or hearing impaired (fourteen pregnant) and thirty-four of thirty-six intact ewes (twenty-three pregnant) were marked with crayon, indicating that they had been mated. Analysis by chi square showed no differences between intact ewes and those with an impaired sense of touch and/or hearing in the proportion mated $\left(\chi^{2}=2.43\right.$; d.f. $=2$, N.S.), but these groups differed significantly $(P<0.001)$ from ewes with an impaired sense of smell. Differences in the proportion of mated ewes which were pregnant were not significant.

The non-pregnant ewes were 'rejoined' with rams in April 1969, and all ewes mated within 17 days.

It appears that when ewes were 'joined' with rams in November, not all the ewes were cycling, and the introduction of rams stimulated oestrous activity only in those ewes which had an intact sense of smell. When 'rejoined' in April, it is supposed that the ewes with an impaired sense of smell had already commenced cycling and mated. These results suggest that rams stimulate oestrous activity in non-cycling ewes through olfactory receptors in the ewe. Sight was not tested in these observations, but Watson \& Radford (1960) have shown that intact vision is not essential for the stimulatory effect to occur.

Skilled technical assistance was given by $\mathrm{Mr}$ A. J. Gharlick, Mr S. R. Wallace and Mr K. E. McCarthy. One of us (P.D.M.) was in receipt of an Australian Wool Board Senior Postgraduate Scholarship.

\section{REFERENCES}

Chapman, H. W. (1965) The anatomy and surgical deprivation of the oral and nasal senses in sheep. M.Sc. thesis, Kansas State University.

FLETCHER, I. C. \& LiNDSAY, D. R. (1968) Sensory involvement in the mating behaviour of domestic sheep. Anim. Behav. 16, 410.

Grono, L. R. (1962) The surgical treatment of canine otitis externa. Aust. vet. J. 38, 235.

PARKes, A. S. \& BRUCE, H. M. (1961) Olfactory stimuli in mammalian reproduction. Science, $\mathcal{N} . \Upsilon$. $134,1049$.

Schinckel, P. G. (1954) The effect of the ram on the incidence and occurrence of oestrus in ewes. Aust. vet. F. 30, 189.

Signoret, J. P. \& MAulÉn, P. (1962) The effect of surgical removal of the olfactory bulbs on the sexual cycle and genital tract of sows. Annls Biol. anim. Biochim. Biophys. 2, 167.

Thompson, D. S. \& Schinckel, P. G. (1952) Incidence of oestrus in ewes. Emp. F. exp. Agric. 20, 77.

Underwood, E. J., Shier, F. L. \& Davenport, N. (1944) Studies in sheep husbandry in Western Australia. V. The breeding season of Merino, crossbred and British breed ewes in the agricultural districts. F. Agric. West Aust., 2nd Ser., 21, 135.

WATson, R. H. \& RADFORD, H. M. (1960) The influence of rams on onset of oestrus in Merino ewes in the spring. Aust. F. Agric. Res. 11, 65. 